Data Analysis or SPSS $/ P C+$ Studentware. Chicago: SPSS, Inc.

\footnotetext{
About the Authors

Pamela H. Rodgers

Pamela $\mathrm{H}$.

Rodgers is an associate professor teaching political science and public administration courses at the University of Wisconsin-La Crosse. Her research interests

include undergraduate survey research projects on citizen participation, the initiative and referendum, and state and local government issues. She participated in the NSFfunded Quantitative Instruction in American Society Program (QIAS) in 1990.
}

Cecilia G. Manrique

Cecilia G. Manrique, assistant professor of political science, University of Wisconsin-La Crosse, has been affiliated with several institutions in both the fields of computing and political science. Two years prior to joining UWL's political science department, she worked as a user services specialist with UWL's Academic Computing Services.

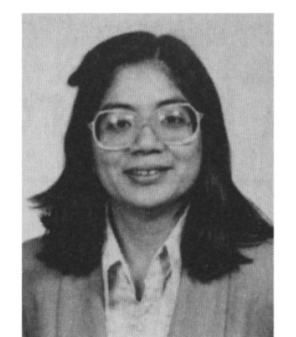

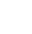

\title{
THE PACIFIC CENTURY New Video and Print Resources for Teaching Asia
}

\author{
by Alex Gibney \\ Executive Producer of THE PACIFIC CENTURY
}

THE PACIFIC CENTURY, a ten-part, ten-hour television series premiering on PBS in the fall of 1992, tries to gaze into the future by looking at the past.

In THE PACIFIC CENTURY we wanted to upset American stereotypes of an exotic and inscrutable orient, while making manifest the strong connections between the United States and the nations of the Pacific Rim. As such, we designed a multidisciplinary series that would mix politics, history, economics, and culture, serving to provide comparative perspectives about contemporary political and economic systems. Undergirding the intellectual solidarity of the series is a group of eminent scholars from diverse disciplines and regional specialties who served as our academic advisors and guides through 150 years of Asia-Pacific history.

To a political scientist such a blend should seem perfectly natural. For it is impossible to understand the modern Asia-Pacific region without a grounding in the regional history of the past 150 years. For example, in the first program, "The Two Coasts of China," we look at the historical tension in China between the insularity and self-sufficiency of the interior and the cosmopolitan character of the coast. It is a tension that still dominates China today. In other programs concerned with Japan, Indonesia, and Vietnam, we show the emergence of strong national movements in response to western colonialism which still color the nationalistic character of the political economies of Asia today.

One cannot understand contemporary Asia (or Europe) without understanding the marriage of convenience between politics and economics. In effect, with this series we sought to rescue an interpretation of Asia from analysts who argued that the capitalist societies in Asia were "just like us." But in highlighting differences, we did not look to "culture"; rather we sought to explain differences in political systems. We tried to shy away from an over-reliance on "cultural" distinctions because we believe that many Americans tend to use "culture" to explain away high-speed economic growth in Asia. At the same time, culture in its widest and truest sense-the totality of socially transmitted history, behavior pattern, arts, beliefs, institutions-is important. We have not tried to ignore cultural differences; we have simply tried to set them in a broader political and historical context.

Most importantly, we have tried to look at Asia from a regional perspective. We believed that prior series on individual countries had been too atomized. In an era of rapid communications and global economics we felt it was important to try to see the Pacific as an interrelated and interdependent region.

This regional approach would bring home to American students the sense of how the Pacific has penetrated their daily lives-from Japanese factories in the U.S. to round-the-clock television coverage of the 1989 demonstrations in and around Tienanmen Square. We also believed that this approach would give students a heightened awareness of the Asian-Pacific character of the United States, as immigrants from Hong Kong, Taiwan, South Korea, and Southeast Asia pour into our major cities. 
Trial Lawyers. Because its experts work pro bono, because its paid staff is small and works from a modest suite in the ABA building in Washington, and because hospitality costs in the host countries are minimal, CEELI has been able to operate inexpensively.

25. In an article in The University of Chicago Law Review (Spring 1991), entitled "Constitutional Politics in Poland: A Report on the Constitutional Committee of the
Polish Parliament," Rapaczynski suggests that the effort to draft a constitution in 1990 may have been premature (see, esp., pp. 606-08, 630-31).

26. Founded at the law school in Bologna, Italy, it recently moved to Venice. J. Woodford Howard, Jr., of Johns Hopkins University, tells me that American legal scholars have discussed joining this effort, but no law school has been willing to take the lead.

\section{About the Author}

Donald L. Robinson is Sylvia D'Lugasch Bauman Professor of Government and American Studies at Smith College.

The Pacific Century: A Television Series

Continued from page 237

We tried to make this an intellectually ambitious series that would also be both emotionally compelling and visually engaging. American students typically lack visual and social images of Asia that can support a more substantive study of the several countries in the region. To help provide American viewers with these significant images, our producers traveled to 12 different countries in the Pacific, filming a cross-section of people from very different walks of life; from a powerful politician in Japan to a group of poor nurses in the Philippines, from a women's rights activist in South Korea to a textile magnate in Hong Kong.

It is our hope and expectation that these ten one-hour programs of THE PACIFIC CENTURY will foster more comprehensive understanding on campuses about the Asia-Pacific region and relations with the United States. We are particularly interested in seeing that the individual programs are used by faculty to encourage knowledgeable debate in courses in comparative politics, international relations, public policy, and as a comparative base study for American politics.

THE PACIFIC CENTURY video series will air on PBS during prime time in fall 1992. The ten programs include:

"The Two Coasts of China: Asia and the Challenge of the West"- treats the collision of East and West in the early 19th century;

"Meiji: Asia's Response to the West"-Japan is the first of the underdeveloped nations to modernize and gain power;

"From the Barrel of a Gun"-the lives of Vietnam's Ho Chi Minh and Indonesia's Sukarno reflect the nationalist movement in those former colonies;

"Writers and Revolutionaries"-Chinese writer Lu Xun and Japanese philosopher Kita Ikki are profiled as intellectuals who play a significant role in promoting social change in their homelands;

"Reinventing Japan"- -examines the transformation during the American occupation after WWII;

"Inside Japan, Inc."-considers the political, historical and cultural roots of Japan's post-war economic miracle;

"Big Business and the Ghost of Confucius"-looks at Asia's newly industrialized countries-Taiwan, South Korea and Singapore;

"The Fight for Democracy"-explores expectations among Asian people for greater political freedom as exemplified by the Republic of Korea;

"Sentimental Imperialists: America in Asia"-looks at American involvement with China and the Philippines; and

"The Pacific Century: The Future of the Pacific Basin"-explores common problems, including pollution, overpopulation, trade friction and immigration shared by the entire region.

If you would like to see a preview videocassette, you may call 1-800-LEARNER. This same contact number handles orders for the complete series ( $\$ 275$ on VHS, or $\$ 29.95$ for a single program).

The print resources that accompany the video series include a new text, Pacific Century: The Emergence of Modern Pacific Asia, by Mark Borthwick, et al.; a study guide, The Pacific Century Study Guide, by Mark Borthwick and Gill Latz; and The Pacific Century Faculty Guide, by Mark Borthwick and Gil Latz. All of these books are available by calling Westview Press at (303) 444-3541. A companion tradebook, The Pacific Century, by Frank Gibney, offers a personal overview of the history and themes of the Pacific basin region, and will be available from Scribner's in early fall. 